University of St. Thomas, Minnesota

UST Research Online

$4-1-2012$

\title{
Permanency and placement planning for older youth with disabilities in out-of-home placement
}

Katharine M. Hill

University of St. Thomas, Minnesota, kmhill1@stthomas.edu

Follow this and additional works at: https://ir.stthomas.edu/ssw_pub

Part of the Clinical and Medical Social Work Commons, and the Social Work Commons

This Article is brought to you for free and open access by the School of Social Work at UST Research Online. It has been accepted for inclusion in Social Work Faculty/Staff Publications by an authorized administrator of UST

Research Online. For more information, please contact asle4660@stthomas.edu. 
Provided for non-commercial research and education use. Not for reproduction, distribution or commercial use.

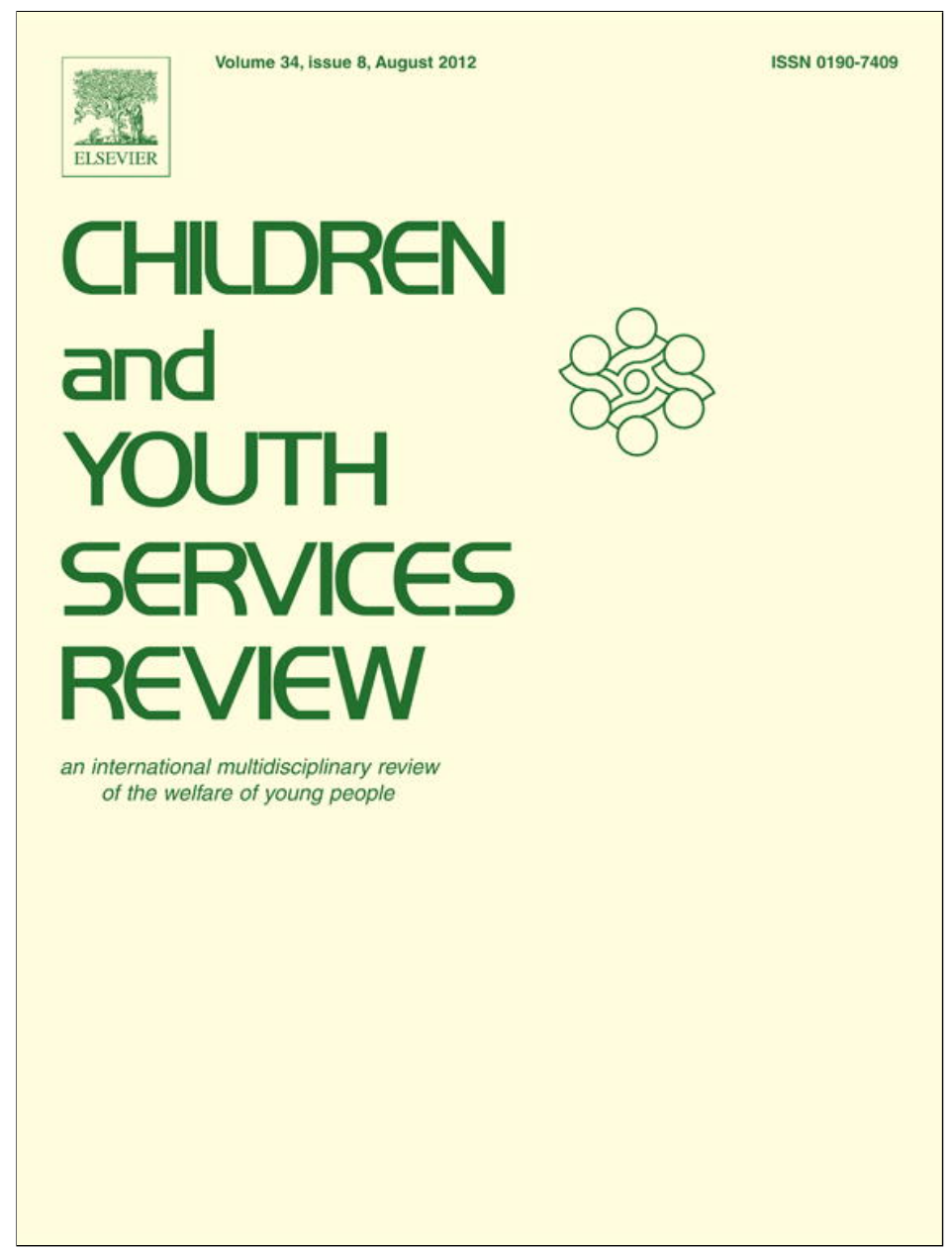

This article appeared in a journal published by Elsevier. The attached copy is furnished to the author for internal non-commercial research and education use, including for instruction at the authors institution and sharing with colleagues.

Other uses, including reproduction and distribution, or selling or licensing copies, or posting to personal, institutional or third party websites are prohibited.

In most cases authors are permitted to post their version of the article (e.g. in Word or Tex form) to their personal website or institutional repository. Authors requiring further information regarding Elsevier's archiving and manuscript policies are encouraged to visit:

http://www.elsevier.com/copyright 


\title{
Permanency and placement planning for older youth with disabilities in out-of-home placement
}

\author{
Katharine Hill * \\ St. Catherine University/University of St. Thomas, School of Social Work, 2115 Summit Avenue, SCB \#201, St. Paul, MN 55105, USA
}

\section{A R T I C L E I N F O}

\section{Article history:}

Received 10 February 2012

Received in revised form 23 March 2012

Accepted 23 March 2012

Available online 1 April 2012

\section{Keywords:}

Disability

Child welfare

Foster care

Placement stability

Permanency

Adolescents

\begin{abstract}
A B S T R A C T
Despite their overrepresentation in the child welfare system (Crosse, Kaye, \& Ratnofsky, 1992; Sullivan \& Knutson, 2000), little is known about the permanency and placement experiences of young people with disabilities in out-of-home placement. Using state administrative data, this study examined the experience of older youth with disabilities in foster care, focusing on placement stability, permanency planning, and placement outcomes. Findings include that older youth with disabilities were more likely to experience longer time in out-of-home placement, and higher rates of placement instability than their peers without disabilities. Additionally, analysis found that only $60 \%$ of the youth in the sample had a concurrent plan on file, and that youth with disabilities have different placement plans than their peers without disabilities. Implications for research, policy, and practice are discussed.
\end{abstract}

(c) 2012 Elsevier Ltd. All rights reserved.

\section{Introduction}

Youth with disabilities are disproportionately represented in the child welfare system (Crosse, Kaye, \& Ratnofsky, 1992; Sullivan \& Knutson, 2000). Due to their higher prevalence rates, as well as the increasing emphasis on rapid achievement of permanency as a result of the Adoption and Safe Families Act, it is likely that children with disabilities are at higher risk to experience disrupted, shortened, or institutional placements (Barth \& Chintapalli, 2009; Kerker \& Dore, 2006; Slayter \& Springer, 2011) than their peers without disabilities, who may be more likely to be reunified, placed with kin, or adopted (Kerker \& Dore, 2006). Thus, there is a need to gain a greater understanding of how these youth are served within the child welfare system (Lightfoot \& LaLiberte, 2006).

Although research on this topic is limited, youth with disabilities who are also in foster care are at risk for particularly poor outcomes, experiencing even lower rates of employment, educational attainment, and economic stability than their nondisabled peers who are aging out of care (Anctil, McCubbin, O'Brien, \& Pecora, 2007a; Anctil, McCubbin, O'Brien, Pecora, \& Anderson-Harumi, 2007b; Zetlin, 2006). Youth with disabilities who are in foster care are almost always involved with multiple service systems and agencies, but are rarely able to experience a seamless, coordinated approach to their care. Instead, they may receive contradictory or duplicative services or may fall through the cracks and receive very few services at all (Geenen \&

\footnotetext{
* Tel.: +1 651962 5809; fax: +1 6519625819

E-mail address: Katharine.hill@stthomas.edu.
}

Powers, 2007; Goerge, VanVoorhis, Grant, Casey, \& Robinson, 1992; Van Wingerden, Emerson, \& Ichikawa, 2002).

This study uses state administrative data in order to compare youth with disabilities emancipating from foster care to their non-disabled peers, examining demographics as well as the differences between the two groups in key child welfare variables, such as length and number of placements, evidence of concurrent permanency planning, and primary placement plan.

\section{Literature review}

Over the past twenty years, studies have found that children and youth with disabilities experience a higher rate of maltreatment than children and youth without disabilities (American Academy of Pediatrics: Committee on Child Abuse and Neglect and Committee on Children with Disabilities, 2001; Crosse et al., 1992; Sullivan \& Knutson, 2000; Verdugo \& Bermejo, 1995; Westcott \& Jones, 1999). For example, Crosse et al. (1992) found that the incidence of maltreatment among children with disabilities was 1.7 times greater than the incidence of maltreatment among children without disabilities, while Sullivan and Knutson (2000) found that children with disabilities were 3.4 times more likely to be maltreated than their nondisabled peers. Lightfoot, Hill, and LaLiberte (2011) found that school-aged children with disabilities were 2.16 times more likely to be in out-of-home placement than youth without disabilities. Other studies put the percentage of children in foster care with disabilities as high as $50-80 \%$, if mental and behavioral health problems are included (Kerker \& Dore, 2006; United Cerebral Palsy and Children's Rights, 2006). A 2004 Government Accountability Office report found that $30-40 \%$ of youth in foster care are afflicted by chronic 
medical problems, and that twice as many youth in foster care have been enrolled in special education than their peers who are not in the child welfare system (United States Government Accountability Office, 2004).

\subsection{Issues with disability identification}

While current research consistently finds that children with disabilities are more likely to experience maltreatment than children without disabilities, and that their experiences of maltreatment may vary based on their disability (Crosse et al., 1992; Sullivan \& Knutson, 2000; Westcott \& Jones, 1999), there is still little known about children with disabilities' experiences within the child welfare system, such as their experiences with placement disruption and permanency. There are several reasons why information regarding child welfare and disabilities is limited. First, state child welfare systems do not collect disability data in a standardized manner, and the Child Abuse Prevention and Treatment Act of 1988 (CAPTA) does not require states to collect such information. As of 2006 , only $33 \%$ of state child welfare systems reported documenting information about specific disabilities of children within their system (Shannon \& Agorastou, 2006). In addition, child welfare workers are often inadequately trained in identifying children with disabilities and in identifying and connecting with disability-specific services and supports (American Academy of Pediatrics: Committee on Child Abuse and Neglect and Committee on Children with Disabilities, 2001; Bonner, Crow, \& Hensley, 1997; Bruhn, 2003; Lightfoot \& LaLiberte, 2006; Shannon \& Agorastou, 2006).

\subsection{Permanency and placement for older youth and youth with disabilities}

The permanency of children in out-of-home placement is a key component of their successful transition to adult life. Research has indicated that stable placements and permanent homes are in the best interests of children in the child welfare system (Barth \& Chintapalli, 2009; Humphrey, Turnbull, \& Turnbull, 2006; Mallon \& Hess, 2005; Rosenberg \& Robinson, 2004). Older youth in care are more likely to experience placement instability than younger children, as well as higher rates of adoption disruption and unsuccessful reunifications (Barth \& Chintapalli, 2009). Youth with disabilities also experience greater placement instability than their non-disabled peers (Brown \& Rodger, 2009; Helton, 2011; Slayter \& Springer, 2011). Rosenberg and Robinson (2004) found that children with medical and developmental problems were more likely to experience longer stays in placement, less likely to be reunified with their parents, more likely to experience placement mobility, and more likely to be placed in more types of outof-home placement (i.e., home foster care, group homes, institutions) than their peers without medical and developmental problems. Similarly, Romney, Litrownik, Newton, and Lau (2006) found that children identified with cognitive, emotional, and physical disabilities at age four were more likely to be placed in non-kin foster care than to be reunified with family. Slayter and Springer (2011) found that youth with intellectual disabilities were 1.4 times more likely to experience a disrupted adoption. Finally, other research has indicated that children with a history of mental illness or emotional or behavioral problems are at greater risk for placement instability and failing to achieve permanence (Akin, 2011; Helton, 2011; James, 2004; Park \& Ryan, 2009). Thus, children and young adults with disabilities are at risk for greater placement disruption, regardless of their disability diagnosis.

Placement instability has been attributed to many causes, including the higher cost of care for these children, their greater demands on both foster and biological families, and a lack of appropriate supports (Akin, 2011; Park \& Ryan, 2009; Rosenberg \& Robinson, 2004; Slayter \& Springer, 2011). Humphrey et al. (2006) found that disability was often a barrier to a youth's adoption, as was being older, while Wells and Guo (1999) found that children with health problems were $39.8 \%$ slower to reunify with their families than children without health problems. Newton, Litrownik, and Landsverk (2000), among others, have found that placement instability is linked with negative effects for the children and youth who experience them; thus the causal link between emotional and behavioral disorders and higher rates of placement disruption is murky at best, as current data do not explicate which "comes first" (Aarons et al., 2010; Leathers, 2006). Thus, it is likely that older youth with disabilities suffer from higher rates of placement disruption and instability than their peers without disabilities.

Given their prevalence in the child welfare system in general and in out-of-home placement specifically, a closer look at the permanency and placement experiences of older youth with disabilities is warranted. This study examines the placement stability and permanency experiences of a sample of older youth with and without disabilities in foster care in one state. Specifically, it seeks to answer:

1. Does having a disability diagnosis impact a youth's placement stability?

2. Does having a disability diagnosis impact a youth's placement outcomes, as measured by the presence or absence of evidence of concurrent planning and types of placements planned?

3. Do youth with specific disability diagnoses (intellectual disabilities, emotional/behavioral disabilities) experience different placement and permanency outcomes than their peers with other types of disabilities?

\section{Methods}

\subsection{Data set}

This project utilized the state administrative data available through the Minn-LInK project at the Center for Advanced Studies in Child Welfare in the University of Minnesota's School of Social Work. MinnLInK is a collaborative, university-based research project to study child and family well being in Minnesota. Minn-LInK relies on secondary administrative data obtained from statewide public programs. Human service programs collect data for multiple purposes: program administration, compliance with federal and state reporting, fiscal management, and local outcome measures; rarely are policy and practice research the intended use of the data. Thus, the findings of this study are somewhat limited, due to the nature of the data.

\subsection{Sample}

The sample for this study is made up of youth who are identified in Minnesota's child welfare data system as: having turned 17 while in foster care; being in out of home placement at any time during 2006, 2007, or 2008; and determined to be in long-term foster care, defined here as being in care for 32 days or more. Based on these criteria, 2385 youth were identified for study inclusion from SSIS data. Next, the SSIS youth were matched, using unique identifiers, with youth in Minnesota's education database. After this process was completed, matching this sample from SSIS with education records, there was a $92 \%$ match, resulting in a sample size of 2187 . Not every youth in the sample had complete records, meaning that the sample size for a given variable fluctuated somewhat. For example, there were 31 young people who did not have disability information in the special education system; thus, the total sample size of youth with disability data (either having or not having a disability) was 2156 .

Once the youth were selected through the matching process, data was gathered back on each through the year of their fourteenth birthday (2002-2004). Fourteen was selected as the starting age for inclusion in the sample because prior to its reauthorization in 2004, IDEA mandated that transition planning for youth with disabilities begin at that age. It is also the age at which Minnesota Education Rules 
require that transition planning begin in special education (Minnesota Administrative Rules 3525.2900).

\subsection{Disability identification}

As previous research has demonstrated, the identification of youth with disabilities in the child welfare system is not always reliable or consistent (Lightfoot et al., 2011; Shannon \& Agorastou, 2006). Therefore, youth were placed in the "disability" group if they had a disability diagnosis in the public special education data system; if they did not have a disability diagnosis in the education system, they were placed in the comparison group of youth in foster care without a disability diagnosis. Based on these criteria, 1312 youth (60\%) had a disability diagnosis and 844 (38.6\%) did not (the remaining 31 youth could not be coded into either category).

Additional analysis was conducted based on youth identified as having emotional behavioral disorders (EBD) or intellectual disabilities as their primary diagnosis in the education data. Of the 1312 young people identified as having a disability, 55\% (722) had EBD as a primary diagnosis, while 136 were identified as having intellectual disabilities. A diagnosis of EBD may include but is not limited to, anxiety disorders, bipolar disorder, conduct disorders, eating disorders, obsessive-compulsive disorder, and psychotic disorders (National Information Center for Children with Disabilities (NICHCY), 2010). Intellectual disabilities, sometimes called mental retardation or cognitive disabilities, is a term used when a child or young adult has limitations in intellectual functioning and in skills such as self-care, social skills, and communication (National Information Center for Children with Disabilities (NICHCY), 2011). In this analysis, EBD was examined in greater detail due to its prevalence in the sample; intellectual disabilities were examined due to the fact that there are specific publicly funded and comparatively widely available services and supports available to people with these disabilities throughout the lifespan, in comparison to many other types of disability.

\subsection{Analysis}

Data analysis was conducted using the Statistical Package for Social Sciences (SPSS). Descriptive statistics (measures of central tendency and chi-square) were used to examine the prevalence of disability, gender, race, and other demographic characteristics of the entire sample. Additionally, the youth with disabilities in the sample were compared with the youth without a disability diagnosis using binary and multinomial logistic regression. Finally, logistic regression analysis was completed comparing youth with either EBD or intellectual disabilities to the rest of the sample with disabilities.

\subsection{Strengths and limitations}

Administrative data, such as that used in this study, may be superior to other types of data (e.g., client recall, caseworker report) in identifying precisely what services were received, when, and in what order (Johnson-Reid \& Drake, 2008). Given the complexity of service systems, it is not uncommon for both frontline workers and clients to have inexact or inaccurate recall of the details of the services provided. Thus, administrative data provides a unique window for study of the experiences of youth with disabilities in out-of-home-placement.

Threats to validity specific to secondary data generally include differences in how variables are defined for research as opposed to recordkeeping and administrative accountability, underreporting or over reporting of certain data points, and improper or rushed datacollection methods by direct service workers (Rubin \& Babbie, 2008; Smith, 2008). Rubin and Babbie (2008) also identify reliability issues as key to the quality of secondary data, as the data may not be an accurate representation of what it claims to report. Minnesota is consistently recognized for having a high quality administrative statewide information system and county child welfare training system (Minnesota Department of Human Services and Safety, (2008, August)). However, some user error, county differences in recordkeeping, and differences in the front-line worker training and understanding of different issues are inevitable, and threaten the reliability of the data (Johnson-Reid \& Drake, 2008).

Perhaps the most critical limitation to this study is the threat of missing data. As with any secondary analysis, crucial data are missing from the data set (Rubin \& Babbie, 2008). However, in the case of this study, the missing data extends beyond simple errors in entering specific data points, instead encompassing a large segment of the study population-youth who appear in one data set and not in another. For example, a youth may be included in one data system (e.g., child welfare), and not in another (e.g., developmental disability services) and there is no way to ascertain which data set is "correct" or the most accurate. The youth's absence from a given system was interpreted as a lack of access to or involvement with that system when this simply may not be the case. The missing data may be a systematic rather than a random error, meaning that the findings will be biased (Sorensen, Sabroe, \& Olsen, 1996). However, given the lack of available information on the population of older youth with disabilities in foster care, as well as the relative nature of that analysis (meaning, analysis comparing two similar groups relative to one another, rather than absolute measures for each individually), then the missing data may be acceptable, although it does weaken the power of the study (Sorensen et al., 1996).

\section{Findings}

Of the 2188 young people in the sample identified as having been in long term foster care during the study years, 1312 had a disability diagnosis in the education system (60\%). The youth with disabilities were more likely to be male than female (65.3 vs. $34.7 \%$ ) and Caucasian (62.3\% of the sample). A relatively low number were identified as Asian (1.6\%) or Hispanic (5.9\%). Table 1 reports these findings, as well as providing data from the United States Office of Special Education Programs (OSEP) for the same state, in order to provide context for the findings. It is notable that the racial and ethnic profile of this sample is markedly different than it is for the state's population of children receiving special education services.

Table 1 also describes the disability diagnosis for the youth in the sample, as were provided by the special education data. The most

Table 1

Sample characteristics.

\begin{tabular}{lll}
\hline & $\begin{array}{l}\text { Sample } \\
\%(\mathrm{n}=1312)\end{array}$ & $\begin{array}{l}\text { OSEP [Minnesota] (U.S. Department of } \\
\text { Education, Office of Special Education } \\
\text { and Rehabilitative Services, \& Office of } \\
\text { Special Education Programs, 2010) }\end{array}$ \\
\hline $\begin{array}{ll}\text { Gender } \\
\text { Male }\end{array}$ & 65.3 & 66.91 \\
Female & 34.7 & 33.09 \\
Race/ethnicity & 62.3 & 75.7 \\
Caucasian & 22.2 & 12.0 \\
African American & 12.7 & 3.5 \\
Native American & 1.6 & 3.5 \\
Asian & 1.4 & - \\
Other & 5.9 & 5.4 \\
Hispanic & & \\
Disability diagnosis & 55.0 & 7.9 \\
Emotional behavioral & 5.9 \\
disorder & & \\
Learning disability & 13.6 & 46.4 \\
Other health impairment & 12.8 & 8.4 \\
Intellectual disabilities & 10.4 & 9.3 \\
Autism & 5.0 & $*$ \\
Multiple disabilities & 2.0 & $*$ \\
Other & 2.0 & 9.2 (all others combined) \\
\hline
\end{tabular}


common disability diagnosis was emotional disturbance (55.0\%), followed by learning disability (13.6\%), other health impairment (12.4\%), and intellectual disability (10.4\%). Again, state-specific data from OSEP are included in this table for comparison with the general population of youth with disabilities. It is notable that emotional disturbance, other health impairments, and autism all seem to be overrepresented in this sample of youth with disabilities aging out of foster care, in comparison to the general population of youth with disabilities, while learning disabilities and ID appear to be underrepresented.

\subsection{Placement stability}

The first research question this study addressed was does a young person's disability status impact their placement stability? Based on descriptive analysis of the data set, presented in Table 2, all of the older youth in the sample experienced a high number of placements (average 5.1 between the ages of 14 and 18) and almost two years (average 23.5 months) in out-of-home care. However, the youth with disabilities in the sample were in out of home placement for a longer period of time (24.7 months on average), had a higher average number of out-of-home placements (5.5 on average), and were less likely to have a concurrent plan for their permanency outcomes.

Table 3 presents multinomial logistic regression analysis of young people's time in placement by disability status and Table 4 presents multinomial logistic regression of the number of placements experienced by the young people during the years encompassed by the data. The multinomial logistic regression model described in Table 3 compares the likelihood of each length of placement variable by disability type. For example, the first column compares the various placement lengths for youth with and without disabilities, with the longest placement ( 3 years or more) as the reference or comparison category. Similarly, the model in Table 4, compares the number of placements with the youth's disability diagnosis, again using the highest value ( 7 or more placements) as the reference or comparison category. Thus, the likelihood of the young people with and without disabilities being placed in each of the three possible placement categories was compared simultaneously.

Youth with disabilities were found to be in placement longer than their peers without disabilities. For example, with three years or more as the reference category, youth with disabilities were 0.70 times as likely to be placed for less than 6 months, and 0.72 times as likely to be placed for between a year and 18 months, than to be in placement for more than 3 years between the age of fourteen and emancipation from care. The youth with disabilities were also found to experience more placements than their peers without disabilities. Using seven or more placements between the age of fourteen and emancipation as the reference category, youth with disabilities were 0.63 times less likely to have between 0 and 3 placements than their peers without disabilities. Thus, youth with disabilities were in out-of-home placement for more time, while also experiencing a higher number of placement changes.

The third research question for this study specifically examined the experiences of youth with EBD or intellectual disabilities while in

Table 2

Placement by disability status.

\begin{tabular}{lccc}
\hline & $\begin{array}{l}\text { Average length of } \\
\text { time in placement } \\
\text { (months) }\end{array}$ & $\begin{array}{l}\text { Average } \\
\text { number of } \\
\text { placements }\end{array}$ & $\begin{array}{l}\text { Evidence of } \\
\text { concurrent } \\
\text { planning }\end{array}$ \\
\hline Full sample & $23.5(\mathrm{sd}=28.9)$ & $5.1(\mathrm{sd}=4.4)$ & $60 \%(924)$ \\
Disability & $24.7(\mathrm{sd}=30.4)$ & $5.5(\mathrm{sd}=4.7)$ & $58.9 \%(545)$ \\
No disability & $21.4(\mathrm{sd}=26.3)$ & $4.6(\mathrm{sd}=3.9)$ & $61.5 \%(365)$ \\
$\begin{array}{l}\text { Emotional behavioral } \\
\quad \text { disabilities }\end{array}$ & $5.61(\mathrm{sd}=4.84)$ & $6.4(\mathrm{sd}=5.03)$ & $62.3 \%(314)$ \\
$\begin{array}{l}\text { Intellectual disabilities } \\
\text { nat }\end{array}$ & $20.75(\mathrm{sd}=53.76)$ & $5.75(\mathrm{sd}=3.13)$ & $48.6 \%(54)$ \\
\hline
\end{tabular}

Table 3

Multinomial regression length of placement.

\begin{tabular}{llll}
\hline Length of placement & All disabilities & $\begin{array}{l}\text { Emotional-behavioral } \\
\text { disorder }\end{array}$ & $\begin{array}{l}\text { Intellectual } \\
\text { disabilities }\end{array}$ \\
\hline $0-6$ months & $0.70^{*}$ & $0.23^{* *}$ & $19.95^{* *}$ \\
& $(0.54-0.92)$ & $(0.16-0.34)$ & $(9.02-44.14)$ \\
6 -12 months & 0.85 & $0.23^{* *}$ & $10.12^{* *}$ \\
& $(0.64-1.12)$ & $(0.16-0.33)$ & $(5.57-18.38)$ \\
1 year-18 months & $0.72^{*}$ & $0.26^{* *}$ & $6.25^{* *}$ \\
& $(0.53-0.98)$ & $(0.17-0.39)$ & $(3.42-11.44)$ \\
18 months-2 years & 1.12 & $0.29^{* *}$ & $4.77^{* *}$ \\
& $(0.79-1.60)$ & $(0.19-0.44)$ & $(2.59-8.78)$ \\
2 years-2 1/2 years & 0.82 & 0.39 & $2.78^{*}$ \\
& $(0.54-1.23)$ & $(0.23-0.66)$ & $(1.43-5.43)$ \\
2 1/2 years to 3 years & 0.82 & 0.74 & 1.56 \\
& $(0.51-1.31)$ & $(0.35-1.39)$ & $(0.79-3.07)$ \\
3 years or more & - & - & - \\
(reference) & & & \\
\hline
\end{tabular}

All disabilities: $\mathrm{R}^{2}$ (Nagelkerke) 0.008. Model $\chi^{2}(6)=12.61, \mathrm{p}=0.05$.

EBD: $\mathrm{R}^{2}$ (Nagelkerke) 0.101, Model $\chi^{2}(6)=5.33, \mathrm{p}<0.000$.

ID: $R^{2}$ (Nagelkerke) 0.202. Model $\chi^{2}(6)=145.35, p<0.000$.

$* \mathrm{p}<0.05$.

$* * \quad \mathrm{p}<0.001$.

out-of-home placement. Comparable models as described previously were tested, using multinomial regression analysis. Similar to the larger group of all youth with disabilities (and using the same reference variable), youth with EBD were found to be less likely to experience shorter time in placement (all values less than 2 years were significant), while youth with intellectual disabilities were found more likely to experience less time in placement (all values less than two years were significant). Youth with intellectual disabilities were also found to be almost five times more likely to experience fewer total placements (4.95 times more likely to experience between 0 and 3); youth with an EBD diagnosis were 3.01 times more likely to experience between 0 and 3 placements than other youth with disabilities. Thus, it would appear that youth with EBD were likely to spend more time in out-of-home care, and have a fewer number of placements than their peers with other disabilities. Youth with intellectual disabilities were in care for less time than other youth with disabilities during their adolescence; however, they also had fewer placements. Therefore, while youth with disabilities may experience greater placement instability than their peers, the type of disability diagnosis may play a role in this, and should be further examined.

\subsection{Concurrent planning and placement plans}

The second research question under consideration in the study was the impact of a disability diagnosis on placement outcomes for young people in the sample, as measured by evidence of concurrent planning and primary placement plans. The findings from this analysis, presented in Table 2, indicate that youth with disabilities

Table 4

Multinomial regression number of placements.

\begin{tabular}{llll}
\hline $\begin{array}{l}\text { Number of } \\
\text { placements }\end{array}$ & All disabilities & $\begin{array}{l}\text { Emotional-behavioral } \\
\text { disorder }\end{array}$ & $\begin{array}{l}\text { Intellectual } \\
\text { disabilities }\end{array}$ \\
\hline $0-3$ & $0.63^{* *}$ & $3.07^{* *}$ & $4.95^{* *}$ \\
& $(0.50-0.78)$ & $(2.28-4.13)$ & $(2.65-9.25)$ \\
$4-6$ & $0.90^{*}$ & $2.11^{* *}$ & $1.94(0.072)$ \\
& $(0.73-1.21)$ & $(1.53-2.91)$ & $(0.94-3.98)$ \\
7 or more & - & - & - \\
\hline
\end{tabular}

All disabilities: $\mathrm{R}^{2}$ (Nagelkerke) 0.015. Model $\chi^{2}(2)=22.98, \mathrm{p}<0.000$.

EBD: $\mathrm{R}^{2}$ (Nagelkerke) 0.065. Model $\chi^{2}(2)=58.62, \mathrm{p}<0.000$.

ID: $\mathrm{R}^{2}$ (Nagelkerke) 0.07. Model $\chi^{2}(2)=38.85, \mathrm{p}<0.000$.

** $\mathrm{p}<0.001$. 
appeared to have a different experience with concurrent planning than youth without disabilities. A binary logistic regression model was tested, looking at the likelihood of youth with and without disabilities experiencing concurrent planning while in out-of-home placement. However, this analysis (Table 5) did not find a significant relationship between a disability diagnosis and evidence of concurrent planning.

Finally a multinomial logistic regression model was tested, examining if youth with disabilities experience different primary placement plans than their non-disabled peers (Table 6). In this model "no plan identified" was the comparison or reference category for possible variables. The analysis found that young people with disabilities were less likely to have reunification (0.52), or relative care (0.44) listed as the placement primary plan. To say this more clearly, youth with disabilities were approximately 1.5 times more likely to have "no plan identified" as their primary placement plan, than to have reunification or relative care identified as their primary plan.

Returning to the third research question of the impact of specific disabilities on placement planning, the logistic regression analysis indicated that, while youth with intellectual disabilities were less likely (0.62) to have a concurrent plan recorded; youth with EBD were more likely (1.37) to have a concurrent plan recorded. Therefore, it would appear that there is a relationship between the types of disability and if a concurrent plan was recorded in the state child welfare data system. There were not any significant findings when the analysis was run for youth with EBD or for youth with intellectual disabilities. Thus, the findings did not indicate a relationship between a specific disability diagnosis and primary placement plan recorded.

\section{Discussion}

The findings from this study raise many questions, due to its exploratory nature. Additionally it is clear from the model fit, as measured by the Nagelkerke $\mathrm{R}^{2}$ values, that a complex set of factors impact young people's experiences in out-of-home placement. However, the analysis does indicate that youth with disabilities are highly prevalent in out-of-home placement, and that their experiences with out-of-home placement and permanency planning differ significantly from that of their non-disabled peers. The cross-systems approach taken by this study begins to document the number and variety of systems and combinations of systems and supports that may be interacting for older youth in care, especially those with disabilities.

\subsection{Child welfare: placements}

The findings from this study indicate that older youth with disabilities in out-of-home placement experience higher rates of placement instability and longer stays in placement. The extant literature indicates that youth who experience placement instability are at higher risk for emotional, educational, mental health, and behavioral problems, as well as poorer adult outcomes (D'Andrade, 2010; Helton, 2011; Pecora, 2010).

Table 5

Logistic regression of concurrent planning by disability status.

\begin{tabular}{llll}
\hline & All disabilities & $\begin{array}{l}\text { Emotional behavioral } \\
\text { disorders }\end{array}$ & $\begin{array}{l}\text { Intellectual } \\
\text { disabilities }\end{array}$ \\
\hline Evidence of concurrent plan & 0.89 & $1.37^{*}$ & $0.62^{*}$ \\
& $(0.72-1.10)$ & $(1.05-1.78)$ & $(0.42-0.93)$ \\
\hline
\end{tabular}

All disabilities: $\mathrm{R}^{2}$ (Nagelkerke) 0.008 . Model $\chi^{2}(1)=5.33, \mathrm{p}=0.02$

EBD: $\mathrm{R}^{2}$ (Nagelkerke) 0.008. Model $\chi^{2}(1)=5.33, \mathrm{p}=0.02$.

ID: $\mathrm{R}^{2}$ (Nagelkerke) 0.011. Model $\chi^{2}(1)=5.42, \mathrm{p}=0.02$.

$* \mathrm{p}<0.05$
Table 6

Multinomial regression of primary permanency by disability.

\begin{tabular}{|c|c|c|c|c|c|c|}
\hline \multirow[t]{2}{*}{ Primary placement } & \multicolumn{2}{|c|}{ Disabilities } & \multicolumn{2}{|c|}{$\begin{array}{l}\text { Emotional } \\
\text { behavioral } \\
\text { disorders }\end{array}$} & \multicolumn{2}{|c|}{$\begin{array}{l}\text { Intellectual } \\
\text { disabilities }\end{array}$} \\
\hline & $\%(n)$ & OR $(95 \% \mathrm{CI})$ & $\%(\mathrm{n})$ & OR $(95 \% \mathrm{CI})$ & $\begin{array}{l}\% \\
(\mathrm{n})\end{array}$ & $\begin{array}{l}\text { OR }(95 \% \\
\text { CI) }\end{array}$ \\
\hline Reunification & & $\begin{array}{l}0.52^{*} \\
(0.28-0.95)\end{array}$ & 139 & $\begin{array}{l}1.00^{* *} \\
(0.51-1.96)\end{array}$ & 40 & $\begin{array}{l}2.06 \\
(0.82-5.14)\end{array}$ \\
\hline $\begin{array}{l}\text { Relative care } \\
\text { (not adoption) }\end{array}$ & & $\begin{array}{l}0.44^{*} \\
(0.22-0.88)\end{array}$ & 6 & $\begin{array}{l}1.26 \\
(0.55-2.90)\end{array}$ & 3 & $\begin{array}{l}2.17 \\
(0.61-7.68)\end{array}$ \\
\hline $\begin{array}{l}\text { Adoption (relatives } \\
\text { and non relatives) }\end{array}$ & & $\begin{array}{l}0.96 \\
(0.47-1.93)\end{array}$ & 35 & $\begin{array}{l}1.11 \\
(0.52-2.40)\end{array}$ & 13 & $\begin{array}{l}2.13 \\
(0.68-6.62)\end{array}$ \\
\hline Long term foster care & & $\begin{array}{l}0.98 \\
(0.52-1.90)\end{array}$ & 58 & $\begin{array}{l}0.59 \\
(0.29-1.17)\end{array}$ & 29 & $\begin{array}{l}0.72 \\
(0.29-1.81)\end{array}$ \\
\hline Independent living & & $\begin{array}{l}0.67 \\
(0.27-1.66)\end{array}$ & 382 & $\begin{array}{l}2.59 \\
(0.78-8.52)\end{array}$ & 108 & \\
\hline Plan not identified & & - & 53 & - & 15 & - \\
\hline
\end{tabular}

All disabilities: $\mathrm{R}^{2}$ (Nagelkerke) 0.027. Model $\chi^{2}(5)=38.47, \mathrm{p}<0.000$

EBD: $\mathrm{R}^{2}$ (Nagelkerke) 0.026. Model $\chi^{2}(5)=21.95, \mathrm{p}=0.001$.

ID: $\mathrm{R}^{2}$ (Nagelkerke) 0.058. Model $\chi^{2}(5)=34.17, \mathrm{p}<0.000$.

$* \mathrm{p}<0.05$.

** $\mathrm{p}<0.001$.

All of the youth in the sample experienced a high rate of placement instability and long duration of placements, averaging five placements between turning 14 and aging out of child welfare, with the average time in placement being 23.5 months. However, youth with disabilities in the sample seemed to experience longer placements as well as a higher number of placements; they move more frequently, but stay in out-of-home care longer than youth without disabilities. Perhaps this can be attributed to the types of placements that they are in; the National Council on Disability (2008) found that youth with disabilities are more likely to be placed in group homes rather than with traditional foster homes. Other reasons may be the difficulties some foster parents report in caring for youth with disabilities, a lack of available supports for the youth and both their foster and biological families, and larger systems issues in providing care (Brown \& Rodger, 2009; D'Andrade, 2010; Helton, 2011; Rosenberg \& Robinson, 2004). Thus, it is clear that child welfare workers and child welfare policymakers need to examine how to stabilize the child welfare experience for older youth with disabilities, so that, if permanency is truly not an option, they are able to live in long-term placements, with caring adults and minimal disruptions. Additionally, further research is needed in order to gain a more nuanced and complete understanding of the experiences of these young people while they are in out-of-home-placement.

\subsection{Child welfare: permanency planning}

The 1997 Adoption and Safe Families Act requires caseworkers to concurrently plan for youths' reunification with family as well as for their adoption (Adoption \& Safe Families Act, 1997). However, only $60 \%$ of the youth in the sample had evidence of a concurrent plan in their child welfare records, despite this federal legal requirement. Additionally, youth with EBD were more likely to have concurrent plans on file, while youth with intellectual disabilities were less likely to have concurrent plans recorded. Of those youth who did have plans, there were significant differences between the plans for youth with disabilities and the plans for youth without a disability diagnosis. Youth with disabilities were half as likely to have either reunification or relative care listed as their primary plan, in contrast to their peers without disabilities.

Although they are inconclusive, these findings raise questions about the interaction of a young person's disability with their placement plans as well as their placement realities. Is there something about the family situations of youth with disabilities that precludes reunification, such as 
a need for greater supports and services than families can provide on their own? Or perhaps the shortened timelines under AFSA prevent caseworkers from providing the needed supports to families of children with disabilities, precluding reunification (Humphrey et al., 2006). Or are the issues that these young people face seen as too complicated or difficult for their families to handle, in comparison to the issues faced by their non-disabled peers? Avery (2000) found that caseworkers' perceptions of the adoptability of children influenced their efforts at recruitment on behalf of that child. Could it be that caseworkers' perceptions of the challenges associated with rearing or placing a specific child impact all areas of permanency planning? While the reality of the majority of youth in the sample is that they will age out of foster care, it is possible that further examination of their permanency plans would provide a window into their placement experiences, as well as their relationships with family and caseworkers, and help to identify areas for effective intervention.

\section{Implications/conclusions}

The findings from this study indicate that there is a need to improve services and supports for older youth with disabilities who are in foster care. The findings support Barbell and Freundlich's (2005) statement that for older youth, foster care is often not a temporary or short-term living situation, but is, instead, a long-term reality. Thus, child welfare workers and foster care providers need to have specific supports and training for children with disabilities. Additionally, efforts should be made to recruit potential adoptive families for children and youth with disabilities (Hanley, 2002). These efforts should extend beyond initial identification and placement and into ongoing education and retention efforts, so that these young people may find permanent homes (Hanley, 2002; James, 2004).

Adoptive families and foster homes are not the only areas for intervention; indeed, supports for the young people themselves are also critical (Hanley, 2002; Trout et al., 2009). For example, Trout et al. (2009) call for additional supports and trainings to be made available to youth with disabilities who are in residential care settings. Similarly, James (2004) suggests that children entering care with specific risk factors, such as age or disability, as well as their foster care providers, receive immediate intervention and support in order to reduce the risk of placement disruption. As well, she argues that a single behavioralrelated placement change serves as a "marker" for the need for immediate intervention, rather than allowing a pattern of placement disruption to develop. Policies and practices that can improve stability for youth, coping skills, and independent living preparation may be very impactful, both in enhancing placement stability, as well as creating better long-term outcomes upon leaving the child welfare system.

Finally, although this research focused on child welfare services and supports, it is undeniable that youth with disabilities are involved with multiple systems of care. There needs to be greater coordination of services and expertise among systems, including, but not limited to, specific disability agencies and advocates, special education, employment supports, and housing providers (Hanley, 2002; Hill, 2009; Lightfoot \& LaLiberte, 2006). Policymakers, administrators, and frontline workers must all support collaboration efforts, in order to make them effective (Hill, 2009; Lightfoot \& LaLiberte, 2006; Slayter \& Springer, 2011); thus, it is critical that efforts to coordinate services occur at all levels. A collaborative approach might help to address this issue, as it would sharpen the focus on the needs of youth, rather than on the needs of systems

\subsection{Conclusion}

It is hoped that by documenting the prevalence of youth with disabilities in out-of-home placement, as well as identifying just a fraction of the barriers and challenges they face to successful adult outcomes, practitioners, policymakers, and other researchers will expand their focus to be more inclusive of youth with disabilities in foster care and begin to actively work to improve services and supports for them, as well as their foster placements, so that they may live happy, productive, and engaged adult lives.

\section{Acknowledgments}

The author would like to acknowledge the advice, assistance, and mentoring of David R. Johnon, Traci LaLiberte, Elizabeth Lightfoot, Yat-Sun (Terry) Lum, and Jessica Toft in the writing of this article.

\section{References}

Aarons, G., James, S., Monn, A., Raghavan, R., Wells, R., \& Lesslie, L. (2010). Behavior problems and placement change in a national child welfare sample: A prospective study. Journal of the American Academy of Child and Adolescent Psychiatry, 49(1), 70-80.

Adoption and Safe Families Act (1997). P.L. 105-89.

Akin, B. (2011). Predictors of foster care exits to permanency: A competing risks analysis of reunification, guardianship, and adoption. Children and Youth Services Review, 33(6), 999-1011.

American Academy of Pediatrics: Committee on Child Abuse and Neglect and Committee on Children with Disabilities (2001). Assessment of maltreatment of children with disabilities. Pediatrics, 108(2), 508-512.

Anctil, T., McCubbin, L., O'Brien, K., \& Pecora, P. (2007). An evaluation of recovery factors for foster care alumni with physical or psychiatric impairments: Predictors of psychological outcomes. Children and Youth Services Review, 29(8), 1021-1034.

Anctil, T., McCubbin, L., O'Brien, K., Pecora, P., \& Anderson-Harumi, C. (2007). Predictors of adult quality of life for foster care alumni with physical and/or psychiatric disabilities. Children and Youth Services Review, 29(8), 1087-1100.

Avery, R. J. (2000). Perceptions and practice: Agency efforts for the hardest-to-place children. Children and Youth Services Review, 22(6), 399-420.

Barbell, K., \& Freundlich, M. (2005). Foster care today. In G. Mallon, \& P. Hess (Eds.), Child welfare for the 21st Century (pp. 504 -517). New York: Columbia University Press.

Barth, R., \& Chintapalli, L. (2009). Permanence and impermanence for youth in out-ofhome care. In B. Kerman, M. Freundlich, \& A. Maluccio (Eds.), Achieving permanence for older children and youth in foster care (pp. 88-108). New York: Columbia University Press.

Bonner, B., Crow, S., \& Hensley, L. (1997). State efforts to identify maltreated children with disabilities: A follow-up study. Child Maltreatment, 2(1), 52-60.

Brown, J., \& Rodger, S. (2009). Children with disabilities: Problems faced by foster parents. Children and Youth Services Review, 31(1), 40-46.

Bruhn, C. (2003). Children with disabilities: Abuse, neglect, and the child welfare system. Journal of Aggression, Maltreatment, and Trauma, 8(1/2), 173-203.

Crosse, S., Kaye, E., \& Ratnofsky, A. (1992). A report on the maltreatment of children with disabilities. Washington, DC: Westat, Inc.

D'Andrade, A. (2010). Placement stability in foster care. In G. Mallon, \& P. Hess (Eds.), Child welfare for the 21st century (pp. 608-622). New York: Columbia University Press.

Geenen, S., \& Powers, L. (2007). “Tomorrow is another problem”: The experiences of youth in foster care during their transition to adulthood. Children and Youth Services Review, 29(8), 1085-1101.

Goerge, R., VanVoorhis, J., Grant, S., Casey, K., \& Robinson, M. (1992). Special education experiences of foster children: An empirical study. Child Welfare, 71, 419-437.

Hanley, B. (2002). Intersection of the fields of child welfare and developmental disabilities. Mental Retardation, 40(5), 413-415.

Helton, J. (2011). Children with behavioral, non-behavioral, and multiple disabilities, and the risk of out-of-home placement disruption. Child Abuse \& Neglect, 35(2011), 956-964.

Hill, K. (1999). Chafee Foster Care Independence Act of 1999: What are the policy implications for youth with disabilities transitioning from foster care. Child Welfare, $88(2), 5-23$.

Humphrey, K., Turnbull, A., \& Turnbull, H. (2006). Impact of the Adoption and Safe Families Act on youth and their families: Perspectives of foster care providers, youth with emotional disorders, service providers, and judges. Children and Youth Services Review, 28(2), 113-132.

James, S. (2004). Why do foster care placements disrupt? The Social Service Review, $78(4), 601-627$

Johnson-Reid, M., \& Drake, B. (2008). Multisector longitudinal administrative databases: An indispensable tool for evidence-based policy for maltreated children and their families. Child Maltreatment, 13(392), 392-399.

Kerker, B., \& Dore, M. (2006). The mental health needs and treatment of foster youth: Barriers and opportunities. The American Journal of Orthopsychiatry, 76(1), 138-147.

Leathers, S. (2006). Placement disruption and negative placement outcomes among adolescents in long-term foster care: The role of behavior problems. Child Abuse \& Neglect, 30(3), 307-324.

Lightfoot, E., Hill, K., \& LaLiberte, T. (2011). Prevalence of children with disabilities in the child welfare system. Children and Youth Services Review, 33(11), 2069-2075.

Lightfoot, E., \& LaLiberte, T. (2006). Approaches to child protection case management for cases involving people with disabilities. Child Abuse E' Neglect, 30(4), 381-391. 
Mallon, G., \& Hess, P. (Eds.). (2005). Child welfare for the 21st century. New York: Columbia University Press.

Minnesota Administrative Rules 3525.2900 (2011). Minnesota Administrative Rules 3525.2900. Transition and behavioral intervention planning. Minnesota Administrative Rule 3525, Children with a disability. Department of Education.

Minnesota Department of Human Services, Child Safety and Permanency Division. (2008, August). Program Improvement Plan (First Submission). Unpublished report.

National Council on Disability (2008). Youth with disabilities in the foster care system: Barriers to success and proposed policy solutions. Washington: Author.

National Information Center for Children with Disabilities (NICHCY) (2010). Emotional disturbances. NICHCY Fact Sheet 5 Retrieved from: http://nichcy.org/disability/specific/ emotionaldisturbance

National Information Center for Children with Disabilities (NICHCY) (2011). Intellectual disabilities. NICHCY Fact Sheet 8 Retrieved from: http://nichcy.org/disability/specific/ intellectual\#def

Newton, R. R., Litrownik, A. J., \& Landsverk, J. A. (2000). Children and youth in foster care: Disentangling the relationship between problem behaviors and number of placements. Child Abuse \& Neglect, 24(10), 1363-1374.

Park, J., \& Ryan, J. (2009). Placement and permanency outcomes for children in out-ofhome care by prior inpatient mental health treatment. Research on Social Work Practice, 19(1), 42-51.

Pecora, P. (2010). Why should child welfare focus on providing placement stability? CW 360: Promoting placement stability. Retrieved from http://www.cehd.umn.edu/ SSw/CASCW/attributes/PDF/publications/CW360_2010.pdf

Romney, S., Litrownik, A., Newton, R., \& Lau, A. (2006). The relationship between child disability and living arrangement in child welfare. Child Welfare, 85(6), 965-984.

Rosenberg, S., \& Robinson, C. (2004). Out-of-home placement for young children with developmental and medical conditions. Children and Youth Services Review, 26 , 711-723.

Rubin, A., \& Babbie, E. (2008). Research methods for social work (6th ed.). Belmont, CA: Thomson Higher Education.

Shannon, P. \& Agorastou, M. (2006). Identifying children with developmental disabilities receiving child protection services: A national survey of child welfare administrators. Families in Society, 87(3), 351-357.
Slayter, E.. \& Springer, C. (2011). Child welfare-involved youth with intellectual disabilities: pathways into and placements in foster care. Intellectual and Developmental Disabilities, 49(1), 1-13.

Smith, E. (2008). Pitfalls and promises: The use of secondary data analysis in educational research. British Journal of Educational Studies, 56(3), 323-339.

Sorensen, H., Sabroe, S., \& Olsen, J. (1996). A framework for evaluation of secondary data sources for epidemiological research. International Journal of Epidemiology, 25(2), 435-442.

Sullivan, P., \& Knutson, J. (2000). Maltreatment and disabilities: A population-based epidemiological study. Child Abuse \&' Neglect, 24(100), 1257-1273.

Trout, A., Casey, K., Chmelka, M., DeSalvo, C., Reid, R., \& Epstein, M. (2009). Overlooked: Children with disabilities in residential care. Child Welfare, 88(2), 111-136.

U.S. Department of Education, Office of Special Education and Rehabilitative Services, \& Office of Special Education Programs (2010). 29th Annual Report to Congress on the Implementation of the Individuals with Disabilities Education Act, 2007, 2, Washington, D.C.: Author.

United Cerebral Palsy and Children's Rights (2006). A case for action for children and youth with disabilities in foster care. Retrieved from http://www.ucp.org/uploads/ ForgottenChildrenFINAL.pdf

United States Government Accountability Office (2004). Foster youth: HHS actions could improve coordination of services and monitoring of states' independent living programs. (GAO-05-25.). Washington, DC: Author.

Van Wingerden, C., Emerson, J., \& Ichikawa, D. (2002). Improving special education for children with disabilities in foster care. (Education Issue Brief). Seattle, WA: Casey Family Services.

Verdugo, M., \& Bermejo, B. (1995). The maltreatment of intellectually handicapped children and adolescents. Child Abuse \& Neglect, 19(2), 205-215.

Wells, K., \& Guo, S. (1999). Reunification and reentry of foster children. Children and Youth Services Review, 21(4), 273-294.

Westcott, H., \& Jones, D. (1999). Annotation: The abuse of disabled children. Journal of Child Psychology and Psychiatry, 40(4), 497-506.

Zetlin, A. (2006). The experiences of foster children and youth in special education. Journal of Intellectual and Developmental Disabilities, 31(3), 161-165. 